PRACE GEOGRAFICZNE

zeszyt $155,2018,47-67$

doi: 10.4467/20833113PG.18.014.9537

Instytut Geografii i Gospodarki Przestrzennej UJ

Wydawnictwo Uniwersytetu Jagiellońskiego

\title{
ODPŁYW RZEKI PRĄDNIK W OJCOWIE W LATACH 1961-2014
}

\author{
Tomasz Bryndal, Rafat Kroczak, Roman Soja, Marta Cieślik
}

\section{Outflow of the Prądnik river in Ojców in the years 1961-2014}

Abstract: Runoff from a karstic catchment (southern part of the Krakow-Częstochowa Upland) was analyzed. The Prądnik-Ojców river gauge station, which closes the upper and the most interesting from the hydrological point of view part of the catchment $\left(67.5 \mathrm{~km}^{2}\right)$, was selected for detailed analyses. The 1961-2014 timespan was studied. Characteristic water discharges and runoff structure were analyzed. Based on the results, water resources were evaluated as large. The specific discharge reached $6.5 \mathrm{dm}^{3} \cdot \mathrm{s}^{-1} \cdot \mathrm{km}^{-2}$, being slightly higher than the average for Poland $\left(5.62 \mathrm{dm}^{3} \cdot \mathrm{s}^{-1} \cdot \mathrm{km}^{-2}\right)$, but comparable to other karstic catchments located in the Upland Belt of Poland. The discharge is stable both in the annual hydrological cycle as well as in the multiannual course. The 53-year long series did not reveal any statistically important tendencies in runoff and the multiannual changes of runoff were predominantly related to changes in precipitation. The structure of runoff is dominated by groundwater runoff, which reached $90 \%$ on average, and the unit groundwater runoff reached $5.8 \mathrm{dm}^{3} \cdot \mathrm{s}^{-1} \cdot \mathrm{km}^{-2}$. This value is a little higher (up to $1.5 \mathrm{dm}^{3} \cdot \mathrm{s}^{-1} \cdot \mathrm{km}^{-2}$ ) in comparison with the neighboring karstic catchments.

Keywords: discharge, runoff, karstic catchment, Kraków-Częstochowa Upland

Zarys treści: W pracy przedstawiono analizę odpływu krasowej zlewni wyżynnej - Prądnika w posterunku Prądnik-Ojców (67,5 km²) w wieloleciu 1961-2014. Analizowano przepływy i odpływy charakterystyczne oraz formy odpływu. Wyniki wykazały, że zlewnia charakteryzuje się dużymi zasobami wody $S S q_{1961-2014}$, wynosi $6.5 \mathrm{dm}^{3} \cdot \mathrm{s}^{-1} \cdot \mathrm{km}^{-2}$. Odpływ jednostkowy jest nieco wyższy niż średnia dla Polski $\left(5,62 \mathrm{dm}^{3} \cdot \mathrm{s}^{-1} \cdot \mathrm{km}^{-2}\right)$. Zlewnia charakteryzuje się wyjątkowo stabilnym odpływem, a prawidłowość tę obserwuje się zarówno w roku hydrologicznym, jak 
również w wieloleciu. Odpływ Prądnika w wieloleciu ulegał zmianom będącym rezultatem zmiennego zasilania zlewni opadami. Lata lub wielolecia z podwyższonym/obniżonym odpływem Prądnika korespondują zwykle z tożsamymi okresami odnotowanymi na innych rzekach Polski. W 53-letniej serii nie stwierdzono istotnych statystycznie zmian odpływu. Podobne zależności charakteryzowały większe rzeki Polski w ostatnim półwieczu. W strukturze odpływu dominuje odpływ podziemny, który jest bardzo wysoki i stanowi średnio $90 \%$, co również wyróżnia Prądnik na tle zlewni regionu. Średni roczny odpływ podziemny z wielolecia wynosi $5,8 \mathrm{dm}^{3} \cdot \mathrm{s}^{-1} \cdot \mathrm{km}^{-2}$, a wartość ta jest o ok. $1,5 \mathrm{dm}^{3} \cdot \mathrm{s}^{-1} \cdot \mathrm{km}^{-2}$ wyższa w porównaniu z sąsiednimi zlewniami.

Stowa kluczowe: przepływ, odpływ, zlewnia krasowa, Wyżyna Krakowsko-Częstochowska

\section{Wprowadzenie}

Krasowiejące skały węglanowe zajmują około $12 \%$ powierzchni kuli ziemskiej (Różkowski i in. 2015). Zlewnie krasowe charakteryzują się dużymi zasobami wód podziemnych (Dynowska, Pociask-Karteczka 1998; Różkowski, Pacholewski 1996; Różkowski i in. 2015), które od dawna były w różny sposób wykorzystywane przez człowieka (Ford, Williams 2007; Soja 2008). Szacuje się, że 25\% całkowitej populacji ludności jest zaopatrywana w wodę pitną ze zbiorników krasowych (Ford, Williams 2007; Różkowski i in. 2015). Jest to jeden z powodów, dla których zasoby wodne w zlewniach krasowych są przedmiotem różnorakich badań szczegółowych (np. Ziemońska 1971; Łajczak 1988; Różkowski 1990; Różkowski, Pacholewski 1996; Różkowski, Żurek, 2008 Perrin, Tournoud 2009; Mayaud i in. 2016), a potrzeba lepszego rozpoznania mechanizmów krążenia wód w tego typu zlewniach jest wciąż podkreślana w literaturze (np. Mayaud i in. 2016).

W problematyce dotyczącej obiegu wody w krasowej zlewni Prądnika dotychczas najlepiej poznano obiekty krenologiczne, głównie za sprawą opracowań m.in. Alexandrowicza i Wilka z 1962 r. (jedna z pierwszych prac tego typu), Dynowskiej (1979), Chełmickiego i in. (2001), Siwka (2004), Siwka i Baścik (2013) i innych. Oprócz badań źródeł, wiele prac dotyczy zagadnień hydrogeologicznych, w których zlewnia Prądnika była częścią większego obszaru badań (np. Różkowski 1990; Różkowski, Pacholewski 1996; Różkowski, Żurek 2008). Kompleksowa analiza odpływu Prądnika w posterunku w Ojcowie, obejmująca odpowiednio długi (ponad 30-letni) ciąg obserwacji (1961-1995), po raz pierwszy została przedstawiona w formie niepublikowanego opracowania, jakim był operat hydrologiczny Ojcowskiego Parku Narodowego - OPN (Soja 1997). Pierwsze publikowane opracowanie będące rozdziałem w monografii OPN zamyka okres do 2005 r. (Soja 2008). Obecnie dostępne dane hydrologiczne pozwalają spojrzeć na odpływ Prądnika z perspektywy ponad 50 lat, a okres ten zdaniem autorów, pozwala w pełni uchwycić sezonowe aspekty formowania odpływu oraz wieloletnie zmiany i trendy w odpływie tej rzeki. 


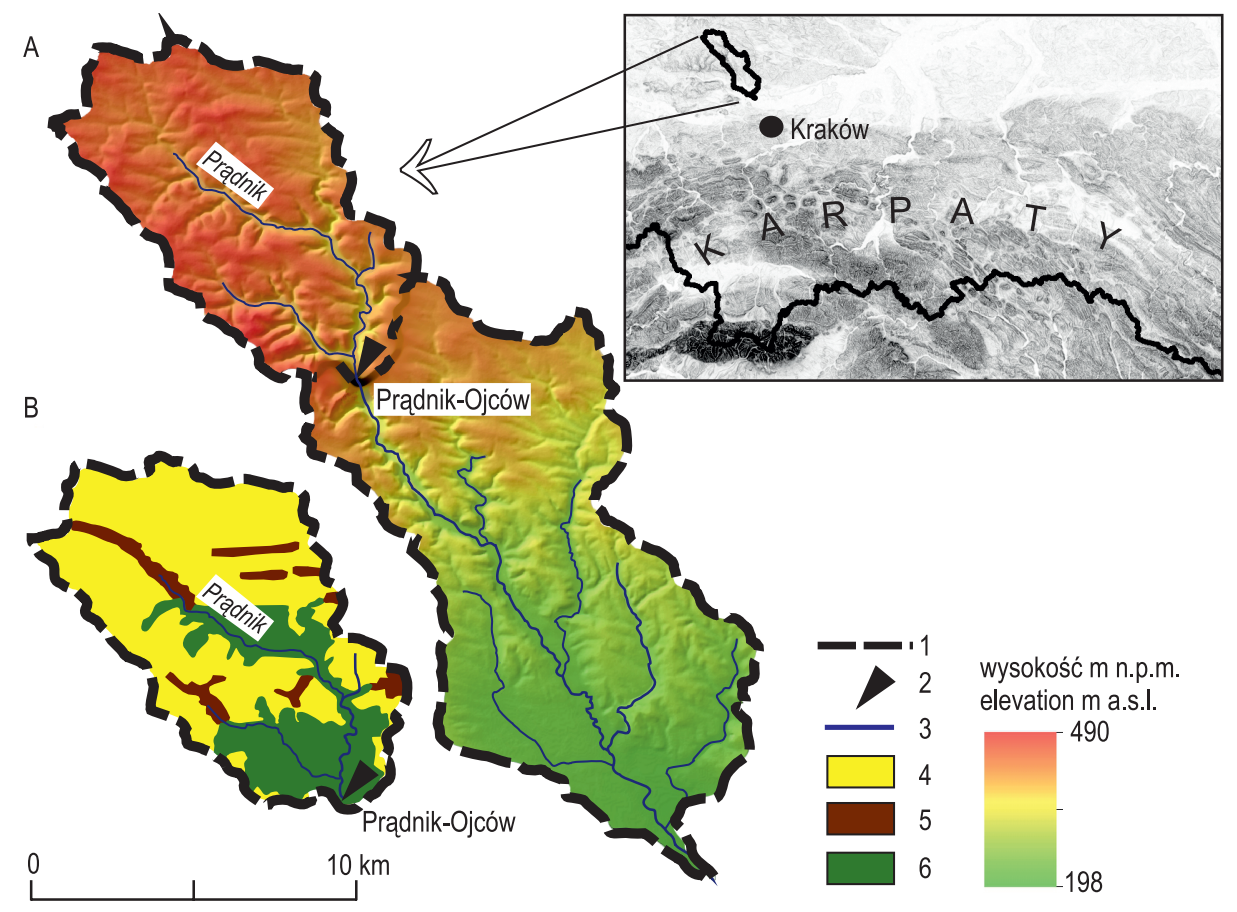

Ryc. 1. Zlewnia Prądnika. A - ukształtowanie powierzchni, B - pokrycie terenu górnej części zlewni

Fig. 1. The Prądnik catchment. A - relief, B - land cover in the upper part of the catchment Objaśnienia: 1 - dział wodny, 2 - posterunek, 3 - cieki, 4 - użytki rolne, 5 - obszary zabudowane, 6 - las. Explanations: 1 -watershed, 2 - rover gauge station, 3 - rivers, 4 -arable areas, 5 - build-up areas, 6 - forest. Źródto: opracowanie własne na podstawie V-mapy.

Source: author's own work based on a V-map. 


\section{Charakterystyka zlewni}

Prądnik jest jedynym lewobrzeżnym dopływem Wisły, do której uchodzi w 81,9 km jej biegu, na obszarze miasta Krakowa. Powierzchnia całej zlewni wynosi 195,80 km², a posterunek Prądnik-Ojców zamyka najbardziej interesującą pod względem hydrologicznym, wyżynną część zlewni.

W podłożu zlewni występują głównie wapienie skaliste i płytowe górnej jury (Pawlak, 1979), natomiast dominującym osadem czwartorzędowym, który pokrywa znaczne obszary zlewni są lessy. Dolina Prądnika jest jarem, wciętym głęboko w falistą wierzchowinę Wyżyny Olkuskiej (ryc. 1). Średnie nachylenie zlewni wynosi $5,2^{\circ}$. Gęstość sieci rzecznej jest mała i wynosi $0,19 \mathrm{~km} \cdot \mathrm{km}^{-2}$ (Soja, 2008).

Wody podziemne występują w kilku poziomach, z których podstawowe znaczenie ma poziom górnojurajski (Płonczyński 2000; Bogacz, Łagiewka 2004). Charakteryzuje się on swobodnym zwierciadłem wody, położonym zazwyczaj na dużych głębokościach (50-73 m p.p.t.), równomiernym zasilaniem oraz zróżnicowaną wydajnością w studniach głębinowych wynoszącą od kilku do $55 \mathrm{~m}^{3} \cdot \mathrm{h}^{-1}$ (Płonczyński 2000). Zasilanie zbiornika górnojurajskiego następuje na całym obszarze jego występowania, bezpośrednio lub pośrednio przez utwory czwartorzędowe. Szczelinowo-krasowy charakter wodonośca i występowanie przepuszczalnego nadkładu sprzyja infiltracji wód atmosferycznych oraz odnawialności zasobów. Wskaźnik infiltracji efektywnej wynosi 26\% (Różkowski, Żurek 2008).

W zlewni funkcjonuje kilkanaście źródeł, które drenują przede wszystkim górnojurajski zbiornik wód podziemnych (Bogacz, Łagiewka 2004). Źródła występują przeważnie na poziomie den dolinnych i w korytach potoków (Bogacz, Łagiewka 2004). Cechują się niską wydajnością - zwykle poniżej $10 \mathrm{dm}^{3} \cdot \mathrm{s}^{-1}$ (Siwek 2004; Siwek, Baścik 2013). W zlewni dominują użytki rolne, które stanowią 70\%. Lasy stanowią $25 \%$, a obszary zabudowane ok. $5 \%$.

\section{Materiały i metody}

Podstawowy materiał stanowiły dobowe przepływy (lata 1971-2014) Prądnika na posterunku w Ojcowie, udostępnione przez IMGW-PIB. Ciąg przepływów dobowych sprawdzono testem Grubbsa-Becka ('Tomalski, Tomaszewski 2015). Wyniki wykazały, że ciąg posiada tzw. wartości odstające, które zweryfikowano, analizując dokumentację fotograficzną wezbrań, gromadzoną w OPN, oraz kronikę Parku. Na podstawie przepływów dobowych obliczono przepływy charakterystyczne dla poszczególnych miesięcy, półroczy i lat (Ozga-Zielińska, Brzeziński 1994). Celem wydłużenia serii uzupełniono je tożsamymi przepływami pochodzącymi z lat 1961-1970, a zamieszczonymi w operacie hydrologicznym OPN (Soja 1997). Do interpretacji zmian 
odpływu wykorzystano również dane dotyczące sum opadów (dobowe - roczne) z posterunku opadowego Ojców (Gospodarstwo Rybackie 1961-89, Park Zamkowy od 1990), udostępnione przez OPN. Z kilku posterunków opadowych położonych wokół zlewni, był on jedynym, dla którego można było uzyskać kompletne dane opadowe dla wielolecia 1961-2014.

Analizę odpływu prowadzono w nawiązaniu do roku hydrologicznego oraz wielolecia. Dla wielolecia 1961-2014 obliczono przepływy $\left(\mathrm{m}^{3} \cdot \mathrm{s}^{-1}\right) \mathrm{i}$ jednostkowe odpływy $\left(\mathrm{dm}^{3} \cdot \mathrm{s}^{-1} \cdot \mathrm{km}^{-2}\right)$ charakterystyczne oraz miarę zróżnicowania, jaką jest współczynnik zmienności $C_{v}(\%)$. Zmiany w wieloleciu analizowano przy pomocy metody krzywej skumulowanych (suma $k-1$ ) różnic współczynników przepływu $k=Q m / S Q m(-)$; gdzie $Q$ - przepływ miesięczny, $S Q m$ - średni przepływ miesięczny w wieloleciu. Pozwala ona wskazać okresy z tendencjami wzrostu lub spadku przepływu oraz wskazać zmiany w tendencji analizowanego zjawiska (Kubiak-Wójcicka 2010). Możliwość pozyskania informacji hydrologicznej o przepływach dla dekady 1961-71 spowodowała, że do wyodrębnienia odpływu podziemnego wybrano metodę Wundta (Bartnik, Jokiel 2000). Obliczono objętość odpływu bezpośredniego (powierzchniowy i podpowierzchniowy) i podziemnego oraz odpowiadające im odpływy jednostkowe ( $q$ pw; $q p d-\mathrm{dm}^{3} \cdot \mathrm{s}^{-1} \cdot \mathrm{km}^{-2}$ ) i warstwy odpływu (Hpw, $H p d-\mathrm{mm}$ ). Badano także współzmienność pomiędzy opadami a odpływem, obliczając współczynniki korelacji krzyżowej $R c$ oraz autokorelację $R a$ w przepływach miesięcznych, w odniesieniu do różnych przesunięć czasowych.

\section{Wyniki}

\section{Przepływy i odpływy charakterystyczne}

Wieloletnią zmienność niskich, średnich i wysokich przepływów oraz odpowiadające im odpływy jednostkowe prezentuje ryc. 2. Najniższe przepływy w dziesięciu $\mathrm{z}$ dwunastu miesięcy mieszczą się $\mathrm{w}$ przedziale $0,20-0,24 \mathrm{~m}^{3} \cdot \mathrm{s}^{-1}$, co odpowiada

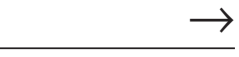

Ryc. 2. Wysokie (A), średnie (B) i niskie (C) przepływy charakterystyczne i odpływy jednostkowe Prądnika w Ojcowie w latach 1961-2014

Fig 2. High (A), medium (B) and low (C) characteristic discharges and specific discharges of the Prądnik river in Ojców in the years 1961-2014

Objaśnienia: Q - przepływ, q - odpływ jednostkowy, $\mathrm{Cv}$ - współczynnik zmienności.

Explanations: $\mathrm{Q}$ - discharge, $\mathrm{q}$ - specific discharge, $\mathrm{Cv}$ - coefficient of variability.

Źródto: obliczenia wtasne na podstawie danych IMGW-PIB i OPN. Dane IMGW-PIB zostały przetworzone. Source: author's own work based on IMGW-PIB and OPN data. The data from IMGW-PIB have been processed. 
A

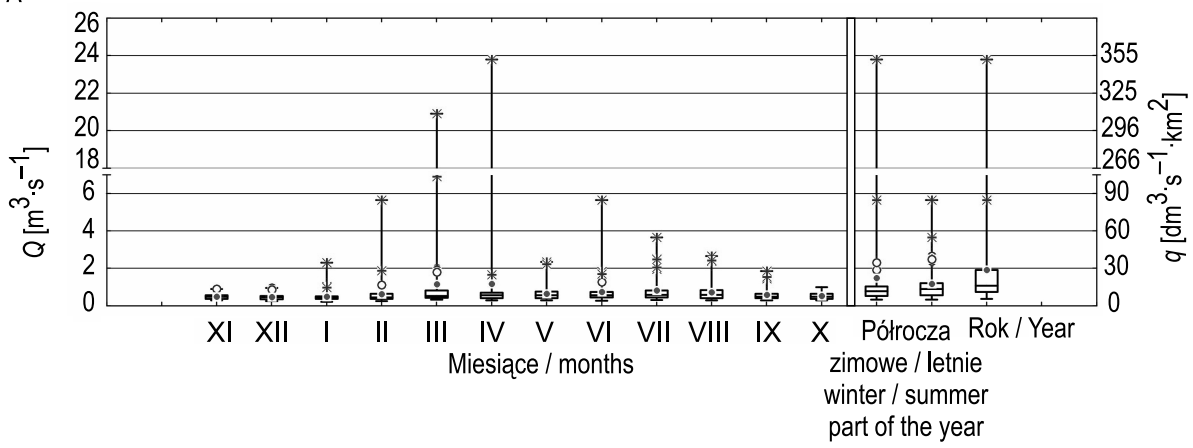

- Mediana / Median
- Średnia / Mean

B

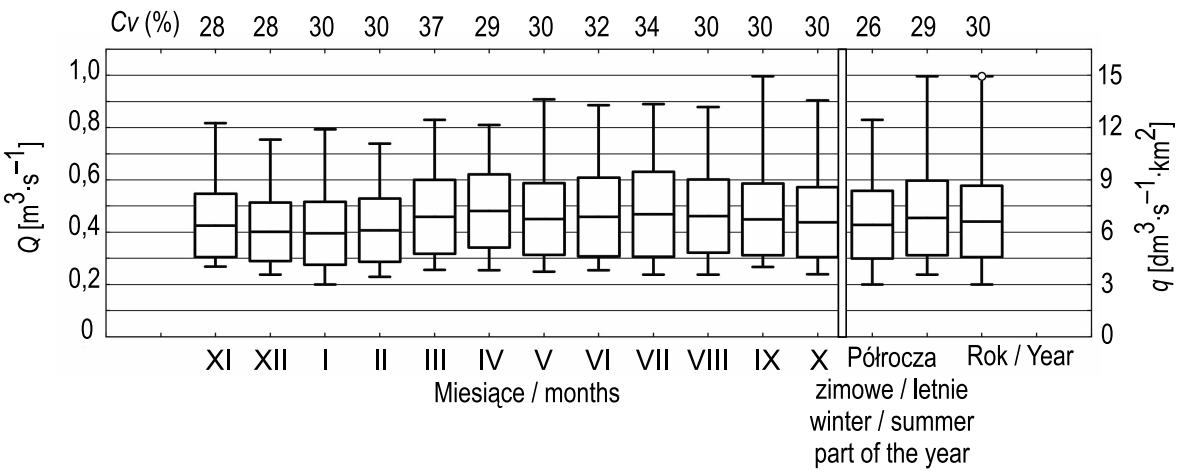

C

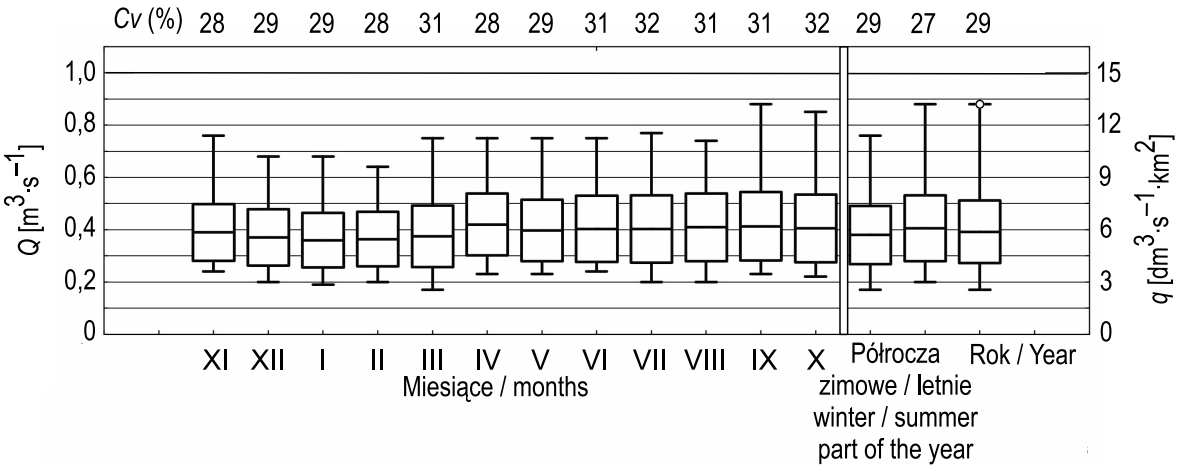

Średnia / Mean

Średnia+-Odch.Std. / Mean+-Std.Dev.

工 Min-Max

○ Odstajace / Outliers 
odpływom jednostkowym od 3,0 do $3,6 \mathrm{dm}^{3} \cdot \mathrm{s}^{-1} \cdot \mathrm{km}^{-2}$ (ryc. 2C). Wartości niższe od $0,2 \mathrm{~m}^{3} \cdot \mathrm{s}^{-1}$ występują $\mathrm{w}$ styczniu i marcu, natomiast najwyższe niskie przepływy notowane są w czerwcu. Roczny przebieg najniższych przepływów charakteryzuje w znacznej mierze wydajność jurajskiego zbiornika wód podziemnych w fazie jego długotrwałego drenażu. Średnie niskie przepływy miesięczne $(S N Q m)$ są przeciętnie o ok. $0,1-0,2 \mathrm{~m}^{3} \cdot \mathrm{s}^{-1}$ wyższe od przepływów najniższych (ryc. 2C). W układzie miesięcznym mieszczą się one w przedziale $0,36-0,42 \mathrm{~m}^{3} \cdot \mathrm{s}^{-1}\left(5,3-6,2 \mathrm{dm}^{3} \cdot \mathrm{s}^{-1} \cdot \mathrm{km}^{-2}\right)$. W kwietniu $S N Q m$ jest zbliżony do średniego przepływu z wielolecia $\left(0,44 \mathrm{~m}^{3} \cdot \mathrm{s}^{-1}\right)$, co jest typowym zjawiskiem w zlewniach o dużych zasobach wodnych (Soja 1997).

Średni ze średnich przepływ roczny $(S S Q)$ dla wielolecia wynosi $0,44 \mathrm{~m}^{3} \cdot \mathrm{s}^{-1}$ $\left(6,5 \mathrm{dm}^{3} \cdot \mathrm{s}^{-1} \cdot \mathrm{km}^{-2}\right)$ i jest podobny w obu półroczach hydrologicznych (ryc. 2B). Przebieg miesięcznych średnich przepływów $(S S Q m)$ jest mało dynamiczny, a wezbrania nie znajdują znaczącego odzwierciedlenia w przepływach średnich. Zaznacza się niewielka kulminacja związana z okresem roztopowym ograniczonym do marca i kwietnia oraz kulminacja lipcowa. Wartości te $\left(0,46-0,48 \mathrm{~m}^{3} \cdot \mathrm{s}^{-1} ; 6,8-7,1 \mathrm{dm}^{3} \cdot \mathrm{s}^{-1} \cdot \mathrm{km}^{-2}\right)$ są nieco wyższe od średniej rocznej z wielolecia $\left(0,44 \mathrm{~m}^{3} \cdot \mathrm{s}^{-1} ; 6,5 \mathrm{dm}^{3} \cdot \mathrm{s}^{-1} \cdot \mathrm{km}^{-2}\right)$. Podobnie jak w przepływach średnich niskich, okres niższych przepływów zaczyna się w grudniu i trwa do lutego (ryc. 2). Najwyższe średnie przepływy miesięczne (WSQm) mieszczą się zwykle w przedziale $0,8-1,0 \mathrm{~m}^{3} \cdot \mathrm{s}^{-1}\left(12-15 \mathrm{dm}^{3} \cdot \mathrm{s}^{-1} \cdot \mathrm{km}^{-2}\right)$.

Średnie wysokie przepływy miesięczne $(S W Q m)$ wykazują maksimum w marcu i kwietniu $\left(1,15-1,17 \mathrm{~m}^{3} \cdot \mathrm{s}^{-1}\right)$, kiedy występuje odwilż, oraz w lipcu $\left(0,82 \mathrm{~m}^{3} \cdot \mathrm{s}^{-1}\right)-$ ryc. 2A. Daje to odpływy jednostkowe ok. $17 \mathrm{dm}^{3} \cdot \mathrm{s}^{-1} \cdot \mathrm{km}^{-2}$ podczas wezbrań wiosennych i ok. $12 \mathrm{dm}^{3} \cdot \mathrm{s}^{-1} \cdot \mathrm{km}^{-2}$ podczas letnich. Najwyższe przepływy miesięczne (WWQm) układają się w sposób nieregularny (ryc. 2A). Od października do grudnia $W W Q$ nie przekraczają $1 \mathrm{~m}^{3} \cdot \mathrm{s}^{-1}$, czyli są o ok. 2,3 razy wyższe od rocznego $S S Q$, co świadczy, że w miesiącach tych występują wezbrania o małych przepływach maksymalnych. W styczniu i lutym WWQm zaczynają stopniowo wzrastać do ok. $6 \mathrm{~m}^{3} \cdot \mathrm{s}^{-1}$, po czym rosną gwałtownie w marcu $\left(20,9 \mathrm{~m}^{3} \cdot \mathrm{s}^{-1}\right)$, osiągając kulminację w kwietniu $\left(23,80 \mathrm{~m}^{3} \cdot \mathrm{s}^{-1}\right)$ i drugą, znacznie niższą w czerwcu $\left(5,65 \mathrm{~m}^{3} \cdot \mathrm{s}^{-1}\right)$. Odpływy jednostkowe w miesiącach wiosennych przekraczają $300 \mathrm{dm}^{3} \cdot \mathrm{s}^{-1} \cdot \mathrm{km}^{-2}$, i są o przeszło 6 razy wyższe od ich odpowiedników letnich (ryc. 2A). Zmienność niskich i średnich przepływów miesięcznych mieści się w przedziale 28-34\% (ryc. 2B, G). Takie wartości wskaźnika $C v$ interpretuje się jako zmienność przeciętną (Zeliaś 2000). Dla przepływów wysokich przeciętną zmiennością $(20 \%<C v<40 \%)$ charakteryzują się tylko trzy miesiące (październik, listopad, grudzień). Dużą zmiennością $(40 \%<C v<100 \%)$ charakteryzują się przepływy w styczniu, maju, oraz miesiące od lipca do września. Pozostałe cztery miesiące (luty, marzec, kwiecień, maj) charakteryzują się Cv>100\%, co oznacza bardzo dużą zmienność w rozkładzie (Zeliaś 2000). 


\section{Przepływy i odpływy charakterystyczne w wieloleciu}

Wieloletni przebieg niskich, średnich i wysokich przepływów miesięcznych i odpowiadających im odpływów jednostkowych, zestawionych jako jeden ciąg dla 53 lat obserwacji przestawiają ryciny 3-5. Test współczynnika korelacji rangowej Spearmana (Ozga-Zielińska, Brzeziński 1994) wskazał, że ciągi przepływów miesięcznych są niejednorodne $(p<0,05)$ dlatego wyniki analiz statystycznych (obliczone zależności regresyjne i trendy) należy analizować bardzo ostrożnie.

W wieloletnim przebiegu niskich przepływów miesięcznych $(N Q m)$ można dostrzec zmiany sezonowe będące odzwierciedleniem rocznego cyklu hydrologicznego oraz wieloletnie zmiany (ryc. 3A). Analizując te miary, można wyróżnić kilka okresów o odmiennym przebiegu odpływu. Od listopada 1961 do września 1982 r. obserwujemy znaczą amplitudę i utrzymywanie się relatywnie wysokich wartości przepływów niskich najczęściej przez jeden, dwa miesiące. Krzywa kumulacyjna $(k-1)$ wskazuje w tym wieloleciu na niewielkie zmiany z tendencją wzrostową odpływu. Można mówić o całych latach z relatywnie dużym odpływem utrzymującym się przez 8-14 miesięcy (ryc. 3A). Lata 1983-1996 to okres o najniższym $\left(2,5-4 \mathrm{dm}^{3} \cdot \mathrm{s}^{-1} \cdot \mathrm{km}^{-2}\right)$ w całym okresie badań odpływie. Kolejny okres to lata 1997-2003, w których przepływy niskie we wszystkich miesiącach roku przewyższają wartość średnią z wielolecia. Można mówić o 6-letnim okresie o wzmożonym odpływie. Okres pomiędzy lipcem 2003 a marcem 2010 r., ponownie zaznacza się niższymi, w stosunku do średniej wieloletniej, przepływami niskimi i jest to kolejny prawie 6-letni okres, o zmniejszonym odpływie $\left(2,8-4,4 \mathrm{dm}^{3} \cdot \mathrm{s}^{-1} \cdot \mathrm{km}^{-2}\right)$. Po marcu 2010 roku zaczyna się kolejny okres, w którym obserwuje się znaczne amplitudy przepływów i tendencję wzrostową odpływu (ryc. 3A). Opisane zmiany w głównej mierze nawiązują do zmian w zasilaniu zlewni (ryc. 6), na co zwrócono uwagę z dyskusji wyników. Zróżnicowanie przepływów niskich jest przeciętne (ryc. 3B). Średnia wartość współczynnika zmienności $C \vartheta$ w wieloleciu wynosi $13 \%$, rzadko przekracza $20 \%$ (ryc. $3 \mathrm{~B}$ ).

Warto również zwrócić uwagę na współczynniki autokorelacji niskich przepływów miesięcznych, obliczone przy różnych przesunięciach miesięcznych $\left(R a_{1-28}\right)$. Pozwalają one ocenić bezwładność odpływu (Jokiel, Tomaszewski 2015; Tomalski, Tomaszewski 2015). Obliczone współczynniki są istotne statystycznie (test Boxa-Ljunga, $p<0,05)$. Współczynniki $R a_{1-3}>0,7$ świadczą o silnej korelacji. Dla kolejnych przesunięć współczynniki wskazują na średnią korelację $\left(0,4<R a_{4-12}<0,7\right)$, a ich wartości maleją powoli (ryc. 3C). Obliczone wartości wskazują na dużą bezwładność odpływu. Odpływy niskie w poszczególnych miesiącach są w dużym stopniu zależne od siebie, a obserwowana duża bezwładność odpływu jest uwarunkowana dużą retencyjnością zlewni. 
A
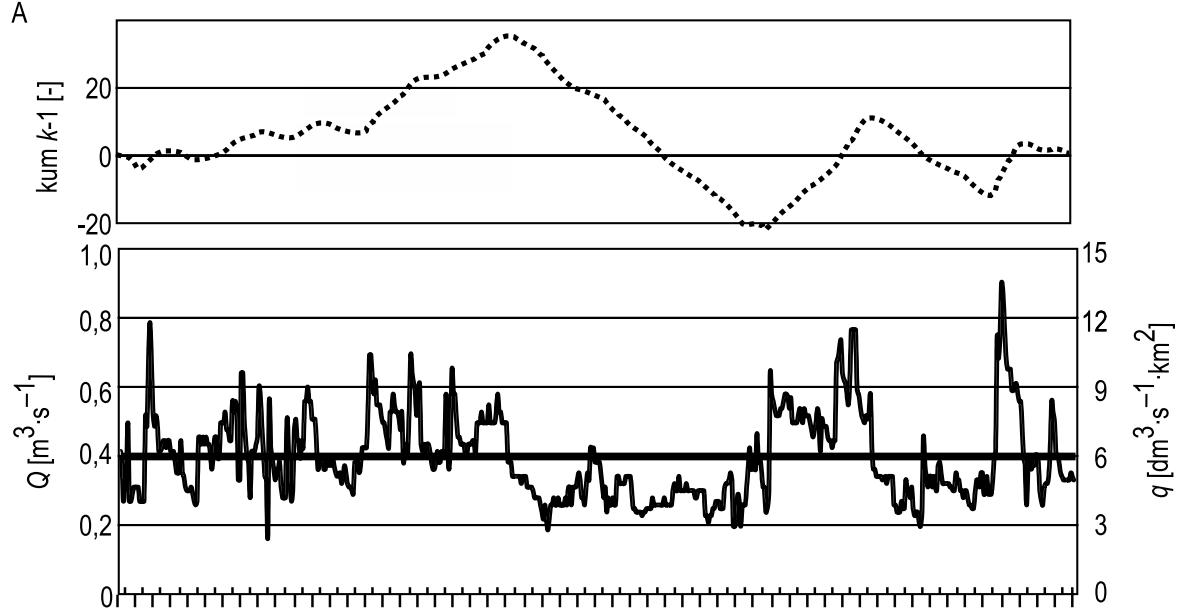

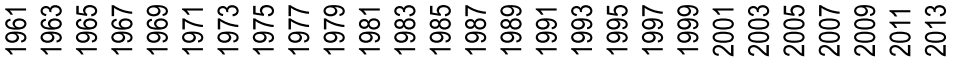

$\mathrm{T}$ [lata / years]

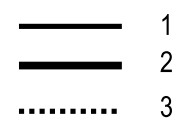

B

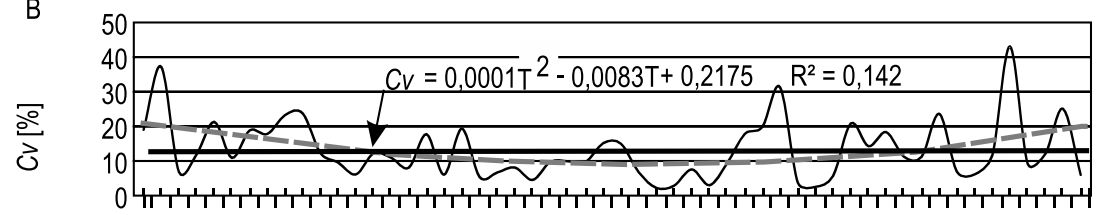

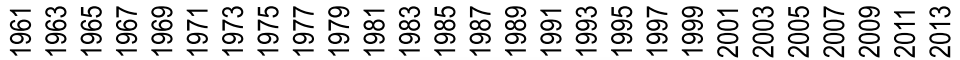

$\mathrm{T}$ [lata / years]

4

5

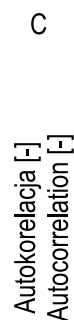
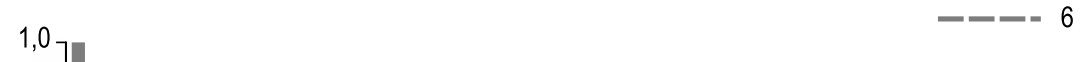

$95 \%$ 
Przebieg średnich przepływów $(S Q m)$ i odpływów jednostkowych dla poszczególnych miesięcy, zestawionych jako jeden ciąg dla 53 lat obserwacji, prezentuje ryc. 4A. Średni przepływ wynosi $0,44 \mathrm{~m}^{3} \cdot \mathrm{s}^{-1}\left(6,5 \mathrm{dm}^{3} \cdot \mathrm{s}^{-1} \cdot \mathrm{km}^{2}\right)$. Największa wartość to wrzesień $2010 \mathrm{r}$. $\left(0,9 \mathrm{~m}^{3} \cdot \mathrm{s}^{-1}-14,7 \mathrm{dm}^{3} \cdot \mathrm{s}^{-1} \cdot \mathrm{km}^{-2}\right)$, a najmniejsza - styczeń $1985 \mathrm{r}$. $\left(0,20 \mathrm{~m}^{3} \cdot \mathrm{s}^{-1}-3,5 \mathrm{dm}{ }^{3} \cdot \mathrm{s}^{-1} \cdot \mathrm{km}^{-2}\right)$. Warto zaznaczyć, że najniższy/najwyższy średni miesięczny przepływ jest zaledwie ok. dwukrotnie niższy/wyższy od wartości średniej z wielolecia $\left(0,44 \mathrm{~m}^{3} \cdot \mathrm{s}^{-1}\right)$. Wyrównanie przepływów średnich Prądnika jest więc wyjątkowo duże, a w wieloletnim przebiegu można wydzielić takie same okresy, jak w przypadku przepływów niskich. Regresja prostolinijna dla przepływów średnich miesięcznych nie wykazała istotnie statystycznie trendu (test Manna-Kendalla, $p<0,05)$ w odpływie. Zróżnicowanie przepływów średnich w świetle wartości współczynnika $C \vartheta$ jest przeciętne (Zeliaś 2000). Średnia wartość $C \vartheta=15 \%$; rzadko przekracza 30\% (ryc. 4B), co wskazuje na dużą stabilizację odpływu. Potwierdzają to również wartości współczynników autokorelacji $\left(R a_{1-2}>0,7 ; R a_{3-8}>0,4\right)-$ ryc. $4 \mathrm{C}$.

Przebieg przepływów wysokich $(\mathrm{WQm})$ i odpływów jednostkowych dla poszczególnych miesięcy, zestawionych jako jeden ciąg dla 53 lat obserwacji prezentuje ryc. 5A. Średnia wartość obliczona z serii wysokich przepływów miesięcznych wynosi $0,73 \mathrm{~m}^{3} \cdot \mathrm{s}^{-1}\left(10,4 \mathrm{dm}^{3} \cdot \mathrm{s}^{-1} \cdot \mathrm{km}^{-2}\right)$ i jest niewiele wyższa od wartości średniej dla przepływów średnich $(S S Q m)$ miesięcznych z wielolecia $-0,44 \mathrm{~m}^{3} \cdot \mathrm{s}^{-1}$ (ryc. 4A). Wskazuje to na dosyć duże wyrównanie przepływów wysokich. Są jednak lata wyraźnie wyróżniające się pod względem tej charakterystyki (ryc. 5A). Najwyższe przepływy występują

$\leftarrow$

Ryc. 3. Niskie miesięczne przepływy i odpływy jednostkowe oraz skumulowane różnice współczynnika przepływu $k$ dla Prądnika w Ojcowie w latach 1961-2014 - A, zróżnicowanie niskich miesięcznych przepływów $\mathrm{w}$ wieloleciu $-\mathrm{B}$, autokorelacje pomiędzy miesiącami - $\mathrm{C}$ Fig. 3. Monthly low discharges, unit discharges and cumulated differences of the flow coefficient $k$ of the Prądnik river in Ojców in the years 1961-2014 - A: Multiannual diversity of the monthly low discharges $-\mathrm{B}$, Autocorrelation between successive months $-\mathrm{C}$

Objaśnienia: $Q$ - przepływ, $q$ - odpływ jednostkowy, 1 - niski przepływ miesięczny, 2 - średni niski przepływ miesięczny, 3 - skumulowane różnice współczynnika przepływu $k$, 4 - współczynnik zmienności, 5 - średnia wartość współczynnika zmienności niskich przepływów miesięcznych, 6 - linia regresji.

Explanations: $Q$ - discharge, $q$ - unit discharge, 1 - monthly low discharge, 2 - mean of the monthly low discharge, 3 - cumulated differences of the flow coefficient $\mathrm{k}, 4$ - coefficient of variability, 5 - average value of the coefficient of variability, 6 - regression line.

Źródto: obliczenia własne na podstawie danych IMGW-PIB i OPN. Dane IMGW-PIB zostały przetworzone. Source: author's own work based on IMGW-PIB and OPN data. The data from IMGW-PIB have been processed. 


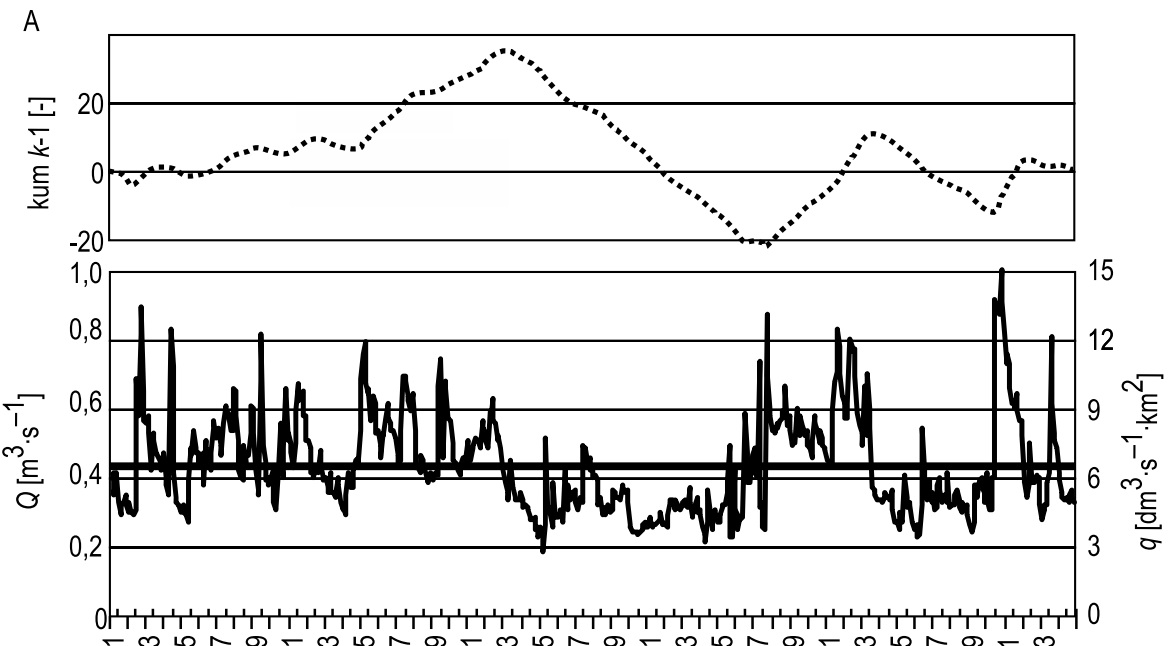

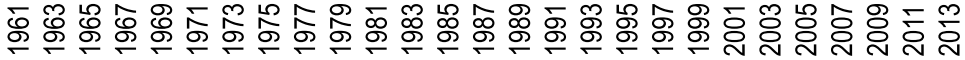

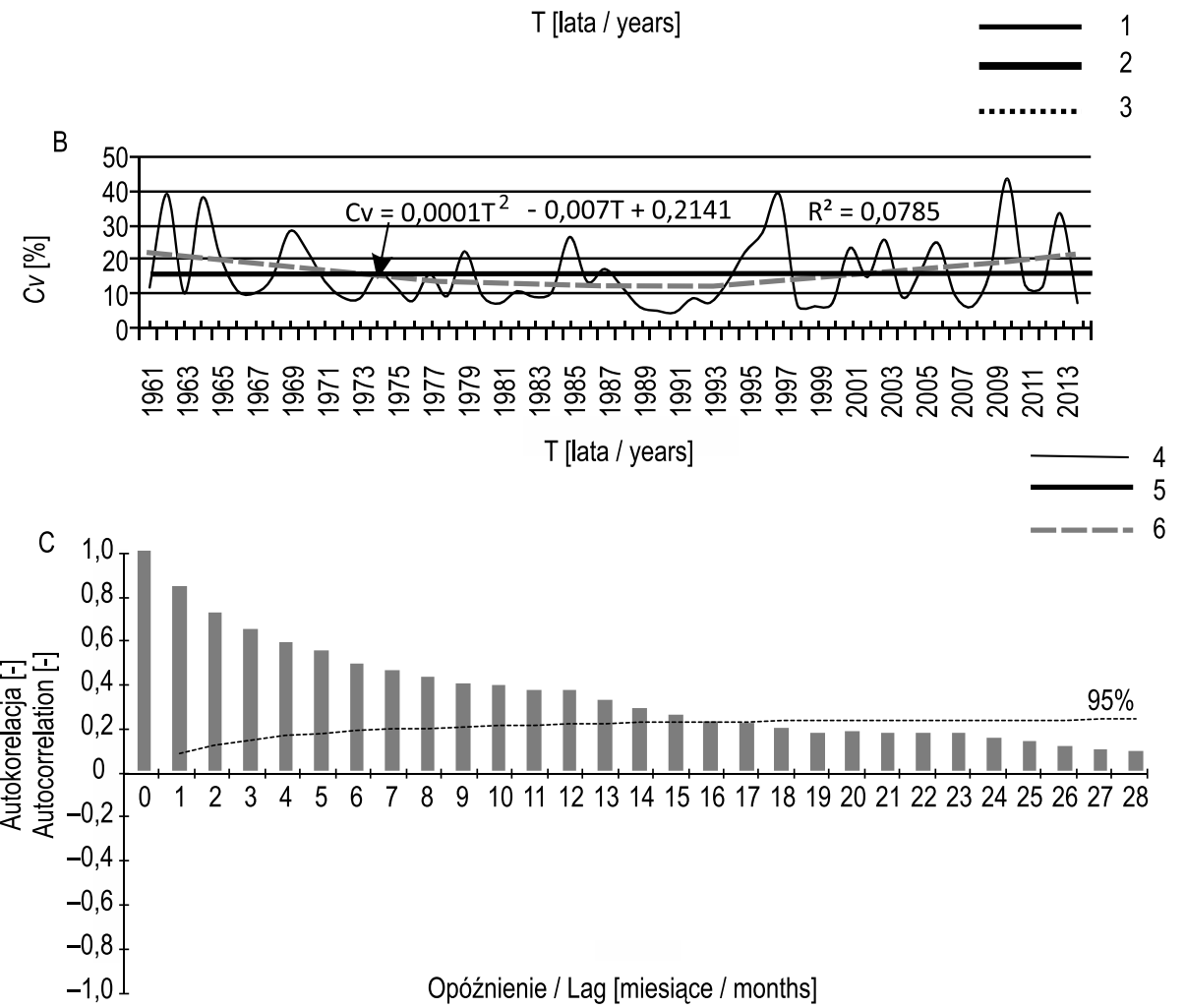


z reguły w półroczu zimowym. Rekordowo wysokie przepływy odnotowano w marcu $\left(20,9 \mathrm{~m}^{3} \cdot \mathrm{s}^{-1} ; 309 \mathrm{dm} \cdot \mathrm{s}^{-1} \cdot \mathrm{km}^{-2}\right)$ i kwietniu $\left(23,8 \mathrm{~m}^{3} \cdot \mathrm{s}^{-1} ; 352 \mathrm{dm}^{3} \cdot \mathrm{s}^{-1} \cdot \mathrm{km}^{-2}\right) 1969 \mathrm{r}$. Było to wezbranie roztopowe, połączone $\mathrm{z}$ opadami deszczu, które wystąpiły głównie w drugiej dekadzie marca $(30,9 \mathrm{~mm})$ oraz na przełomie marca i kwietnia (31.03-10.4 - 15,8 mm), a spływ po zamarzniętym podłożu odegrał znaczącą rolę w kształtowaniu przepływów maksymalnych. Wysoki przepływ wystąpił również w marcu i kwietniu 1964 r. $\left(6,9 ; 7,66 \mathrm{~m}^{3} \cdot \mathrm{s}^{-1}-102 ; 113 \mathrm{dm} \mathrm{dm}^{3} \cdot \mathrm{s}^{-1} \cdot \mathrm{km}^{-2}\right)$. W wezbraniu marcowym ważną rolę mogły również odegrać opady deszczu z dnia 29 marca (16,9 $\mathrm{mm})$.

W analizowanym ciągu przepływy wezbraniowe odnotowane podczas miesięcy letniego półrocza hydrologicznego są kilkukrotnie niższe. Zwykle mieszczą się w przedziale od 1 do $2,5 \mathrm{~m}^{3} \cdot \mathrm{s}^{-1}\left(15-37 \mathrm{dm}^{3} \cdot \mathrm{s}^{-1} \cdot \mathrm{km}^{-2}\right), \mathrm{z}$ maksimum $5,65 \mathrm{~m}^{3} \cdot \mathrm{s}^{-1}$ $\left(84 \mathrm{dm}^{3} \cdot \mathrm{s}^{-1} \cdot \mathrm{km}^{-2}\right)$ zanotowanym w $1965 \mathrm{r}$. W analizowanym wieloleciu wezbrania takie odnotowano w 28 miesiącach, w tym trzykrotnie przekroczyły wartość $2,5 \mathrm{~m}^{3} \cdot \mathrm{s}^{-1}$. Analizując przepływy wysokie, warto wspomnieć o wezbraniu z dnia 18 maja 1996 r. z przepływem szacowanym na $32 \mathrm{~m}^{3} \cdot \mathrm{s}^{-1}-474 \mathrm{dm}^{3} \cdot \mathrm{s}^{-1} \cdot \mathrm{km}^{-2}$ (Niedbała, Soja 1998). Było to wezbranie spowodowane opadami nawalnymi, które wystąpiły w źródłowej części zlewni na terenie wsi Sułoszowa. W czasach historycznych podobnej genezy wezbrań w zlewni Prądnika było kilka (Kondracki 1937; Partyka 1999), jednakże brak dla nich danych hydrologicznych. Dla przepływów wysokich miesięcznych autokorelacje $R a$, wynoszą 0,45 . Dla pozostałych przesunięć są mniejsze od 0,01 . Świadczy to o dużym udziale czynnika losowego w występowaniu wysokich przepływów.

$\leftarrow$

Ryc. 4. Średnie miesięczne przepływy i odpływy jednostkowe oraz skumulowane różnice współczynnika przepływu $k$ dla Prądnika w Ojcowie w latach 1961-2014 - A, zróżnicowanie średnich miesięcznych przepływów w wieloleciu - B, autokorelacje pomiędzy miesiącami-C Fig. 4. Monthly medium discharges, unit discharges and cumulated differences of the flow coefficient $k$ of the Prądnik river in Ojców in the years 1961-2014 - A: Multiannual diversity of the monthly medium discharges $-\mathrm{B}$, Autocorrelation between successive months - $\mathrm{C}$

Objaśnienia: $Q$ - przepływ, $q$ - odpływ jednostkowy, 1 - średni przepływ miesięczny, 2 - średni średni przepływ miesięczny, 3 - skumulowane różnice współczynnika przepływu $k$, 4-współczynnik zmienności, 5 - średnia wartość współczynnika zmienności średnich przepływów miesięcznych, 6 - linia regresji.

Explanations: $Q$ - discharge, $q$ - unit discharge, 1 - monthly medium discharge, 2 - mean of the monthly medium discharge, 3 - cumulated differences of the flow coefficient $\mathrm{k}, 4$ - coefficient of variability, 5 - average value of the coefficient of variability, 6 - regression line.

Źródto: obliczenia własne na podstawie danych IMGW-PIB i OPN. Dane IMGW-PIB zostały przetworzone. Source: author's own work based on IMGW-PIB and OPN data. The data from IMGW-PIB have been processed. 


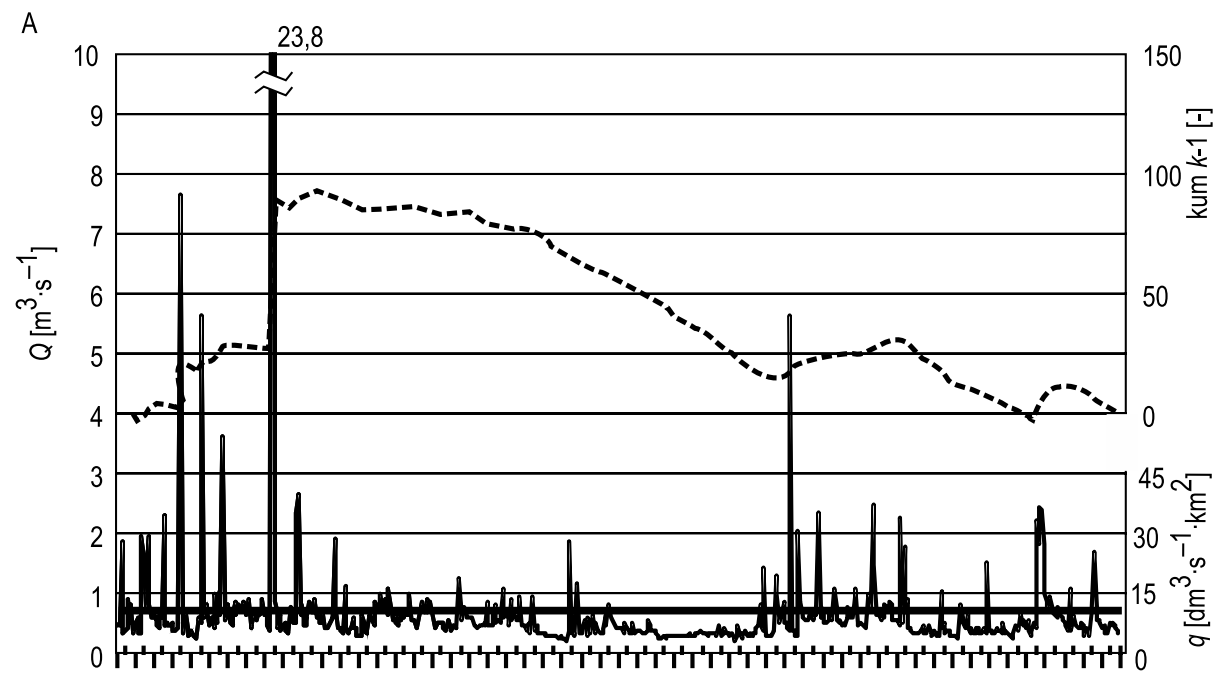

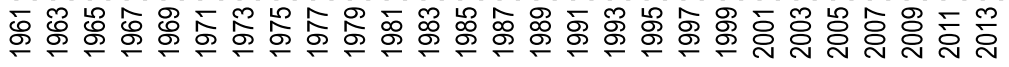

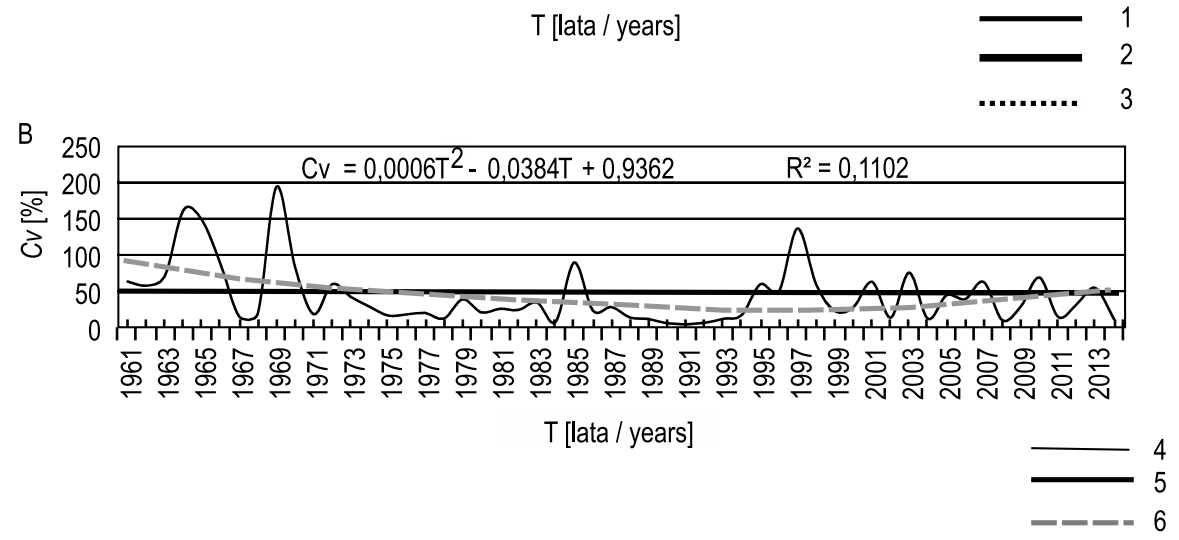

Ryc. 5. Wysokie miesięczne przepływy i odpływy jednostkowe oraz skumulowane różnice współczynnika przepływu $k$ dla Prądnika w Ojcowie w latach 1961-2014 - A, zróżnicowanie wysokich miesięcznych przepływów w wieloleciu - B, autokorelacje pomiędzy miesiącami-C Fig. 5. Monthly high discharges, unit discharges and cumulated differences of the flow coefficient $k$ of the Prądnik river in Ojców in the years 1961-2014 - A, Multiannual diversity of the monthly high discharges $-\mathrm{B}$, Autocorrelation between successive months - C

Objaśnienia: $Q$ - przepływ, $q$ - odpływ jednostkowy, 1 - wysoki przepływ miesięczny, 2 - średni wysoki przepływ miesięczny, 3 - skumulowane różnice współczynnika przepływu $k$, 4-współczynnik zmienności, 5 - średnia wartość współczynnika zmienności wysokich przepływów miesięcznych, 6 - linia regresji. Explanations: $Q$-discharge, $q$ - unit discharge, 1 - monthly high discharge, 2 - mean of the monthly high discharge, 3 - cumulated differences of the flow coefficient k, 4 - coefficient of variability, 5 - average value of the coefficient of variability, 6 - regression line.

Źródto: obliczenia własne na podstawie danych IMGW-PIB i OPN. Dane IMGW-PIB zostały przetworzone Source: author's own work based on IMGW-PIB and OPN data. The data from IMGW-PIB have been processed. 


\section{Odpływ całkowity i jego formy}

Odpływ całkowity Prądnika oraz jego formy w ciągu roku hydrologicznego wyrażony w postaci odpływów jednostkowych i współczynników odpływu powierzchniowego oraz zasilania podziemnego prezentuje tab. 1. Analiza tych danych wskazuje, że odpływ całkowity Prądnika w ciągu roku jest bardzo wyrównany.

Średnie miesięczne odpływy jednostkowe w wieloleciu 1961-2014 wahają się w przedziale $6-7 \mathrm{dm}^{3} \mathrm{~s}^{-1} \cdot \mathrm{km}^{-2}$. Nieco niższe wartości występują w półroczu zimowym niż letnim (tab. 1). W strukturze odpływu dominuje odpływ podziemny, który średnio stanowi 90\%, a jego przebieg w ciągu roku ma małą dynamikę. Tylko w marcu, kiedy wody roztopowe spływają po zamarzniętym podłożu, szybko osiągając koryto cieku, udział odpływu podziemnego w odpływie całkowitym zmniejsza się

Tabela 1. Średnie odpływy jednostkowe Prądnika w Ojcowie w latach 1961-2014 oraz współczynniki odpływu powierzchniowego i zasilania podziemnego

Table 1. Average unit outflow of the Prądnik river in Ojców for the years 1961-2014, the direct outflow and groundflow coefficients

\begin{tabular}{|c|c|c|c|c|c|c|c|c|c|c|c|c|c|c|c|}
\hline \multirow{3}{*}{$\begin{array}{l}\text { Odpływ } \\
\text { Outflow }\end{array}$} & \multirow{2}{*}{\multicolumn{12}{|c|}{$\begin{array}{l}\text { Miesiące } \\
\text { Months }\end{array}$}} & \multirow{3}{*}{ XI-IV } & \multirow{3}{*}{$V-X$} & \multirow{3}{*}{$I X-X$} \\
\hline & & & & & & & & & & & & & & & \\
\hline & $X I$ & XII & I & II & III & IV & V & $\mathrm{Vl}$ & VII & VIII & IX & $x$ & & & \\
\hline & \multicolumn{15}{|c|}{$\left(\mathrm{dm}^{3} \cdot \mathrm{s}^{-1} \cdot \mathrm{km}^{-2}\right)$} \\
\hline qcat & 6,3 & 6,0 & 5,9 & 6,0 & 6,8 & 7,1 & 6,7 & 6,8 & 6,9 & 6,8 & 6,6 & 6,5 & 6,3 & 6,7 & 6,5 \\
\hline$q p w$ & 0,5 & 0,5 & 0,5 & 0,6 & 1,2 & 0,9 & 0,8 & 0,8 & 1,0 & 0,8 & 0,5 & 0,5 & 1,4 & 1,5 & 1,9 \\
\hline qpod & 5,8 & 5,5 & 5,3 & 5,4 & 5,5 & 6,2 & 5,9 & 6,0 & 6,0 & 6,1 & 6,1 & 6,0 & 5,6 & 6,0 & 5,8 \\
\hline \multicolumn{16}{|c|}{$(\%)$} \\
\hline WZpow & 8 & 8 & 9 & 10 & 17 & 12 & 11 & 11 & 12 & 11 & 8 & 8 & 11 & 10 & 10 \\
\hline WZpod & 92 & 92 & 91 & 90 & 83 & 88 & 89 & 89 & 88 & 89 & 92 & 92 & 89 & 90 & 90 \\
\hline
\end{tabular}

Objaśnienia: qcat - jednostkowy odpływ całkowity, qpw - jednostkowy odpływ bezpośredni (powierzchniowy i podpowierzchniowy), qpod - jednostkowy odpływ podziemny, WZpow - współczynnik odpływu powierzchniowego, WZpod - współczynnik zasilania podziemnego.

Explanations: qcat - unit total outflow, qpw - unit direct outflow (surface and subsurface), qpod - unit groundwater outflow, WZpow-direct outflow coefficient, WZpod-groundflow coefficient .

Źródto: obliczenia własne na podstawie danych IMGW-PIB i OPN. Dane IMGW-PIB zostały przetworzone. Source: author's own work based on IMGW-PIB and OPN data. The data from IMGW-PIB have been processed. 
do $83 \%$, ale już w kwietniu jego udział ponownie wzrasta do $88 \%$. Od listopada do lutego oraz we wrześniu i październiku odpływ podziemny stanowi więcej niż $90 \%$ odpływu całkowitego. W strukturze odpływu składowa powierzchniowa najwyższe wartości osiąga w marcu, kiedy występują największe wezbrania roztopowe. Nieco mniejsze wartości przejmuje ona w miesiącach, w których wezbrania formowane są w wyniku opadów deszczu.

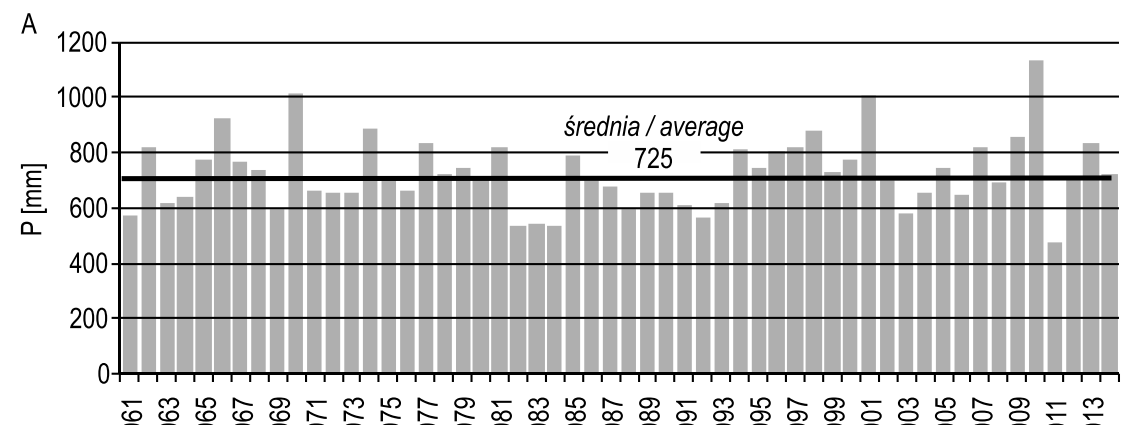

$\mathrm{B}$

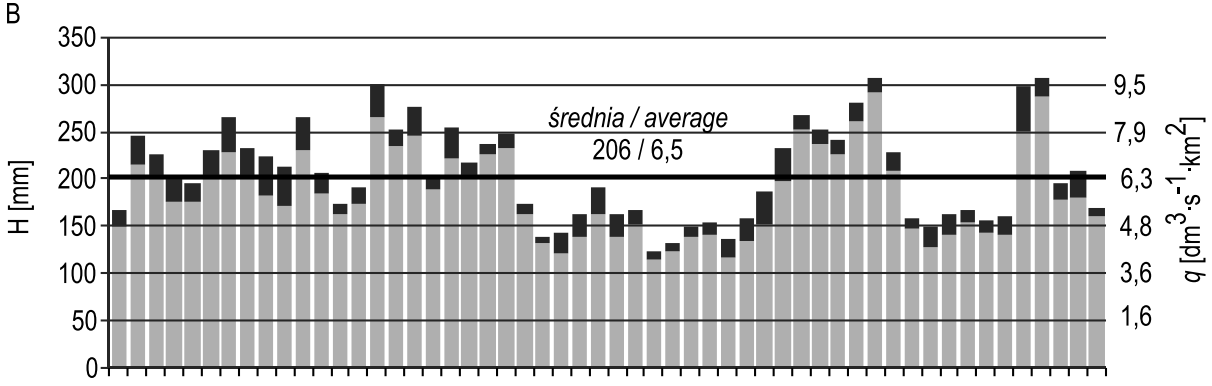

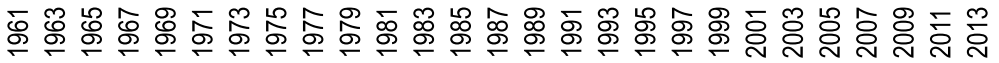

C
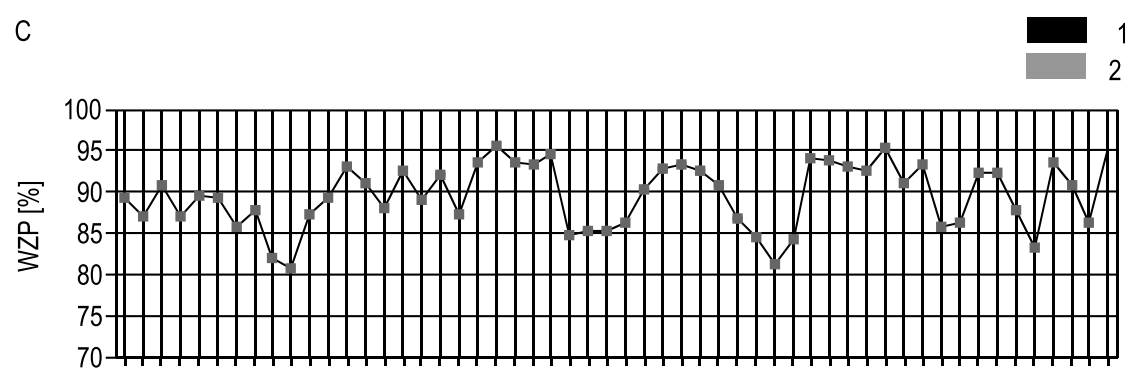

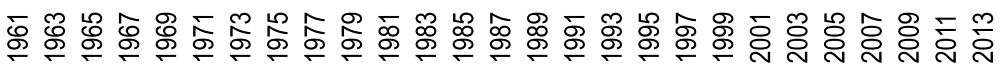

T [lata / years] 
W wieloleciu średni jednostkowy odpływ wynosi $6,5 \mathrm{dm}^{3} \cdot \mathrm{s}^{-1} \cdot \mathrm{km}^{-2}$, a składowa podziemna stanowi średnio ok. 90\% (ryc. 6B, C). Najniższe wartości współczynnika zasilania podziemnego wystąpiły w wybitnie wilgotnym roku 1970 (81\%). W latach 1981 i 2002 96\% odpływu było pochodzenia podziemnego. Podwyższone wartości odpływu podziemnego są zwykle skutkiem wyższych sum opadów roku uprzedniego (ryc. 6A, B), które zasilają górnojurajski zbiornik wód podziemnych.

\section{Dyskusja}

Średni roczny odpływ Prądnika $S S q_{1961-2014}$ wynosi $6,5 \mathrm{dm}^{3} \cdot \mathrm{s}^{-1} \cdot \mathrm{km}^{-2}$. Jest on nieco wyższy niż średnia dla Polski - 5,62 $\mathrm{dm}^{3} \cdot \mathrm{s}^{-1} \cdot \mathrm{km}^{-2}$ (Michalczyk 2017). Odpływ Prądnika jest porównywalny z odpływem notowanym w sąsiadujących zlewniach krasowych - 6-8 $\mathrm{dm}^{3} \cdot \mathrm{s}^{-1} \cdot \mathrm{km}^{-2}$ (Dynowska 1971; Stachy, Biernat 1987; Różkowski, Pacholewski 1996; Jokiel 2004), mimo iż warunki geologiczne i krążenie wód podziemnych (Dynowska 1979), które zasilają te rzeki, jest nieco inny. Podobne odpływy jednostkowe występują w zlewniach na Wyżynie Lubelskiej (Stachy, Biernat 1987).

Prądnik charakteryzuje się stabilnym odpływem. Potwierdzają to charakterystyki opisujące przebieg niskich i średnich odpływów charakterystycznych. Prawidłowość ta jest zauważalna zarówno w odniesieniu do roku hydrologicznego (ryc. 2B, C), jak i wielolecia (ryc. 3, 4). Stabilność odpływu uwarunkowana jest dużą retencyjnością zlewni, na co wskazują wysokie wartości współczynnika zasilania podziemnego - ryc. 6 (śr. WZP ${ }_{1961-2014}=90 \%$ ).

\section{$\leftarrow$}

Ryc. 6. Wieloletnie zmiany w opadach - A, składowych odpływu - B oraz współczynniku zasilania podziemnego - C Prądnika w Ojcowie w latach 1961-2014

Fig. 6. Multiannual changes in precipitation - A, structure of the outflow - B, and the groundflow coefficient - C of the Prądnik river in Ojców in the years 1961-2014

Objaśnienia: $P$ - opady roczne na posterunku Ojców, H - wskaźnik odpływu, q - jednostkowy odpływ, 1 - bezpośredni (powierzchniowy i podpowierzchniowy), 2 - podziemny, średnia - średnia wartość z wielolecia, WZP - współczynnik zasilania podziemnego.

Explanations: $\mathrm{P}$ - yearly precipitation in the Ojców gauge station, $\mathrm{H}$ - outflow coefficient, q-unit outflow, 1 - direct outflow (surface and subsurface), 2 - groundflow, WZP - groundflow coefficient.

Źródto: obliczenia własne na podstawie danych IMGW-PIB i OPN. Dane IMGW-PIB zostały przetworzone. Source: author's own work based on IMGW-PIB and OPN data. The data from IMGW-PIB have been processed. 
Wysokie przepływy notowane są głównie w półroczu zimowym i związane są z roztopami spowodowanymi adwekcją ciepłych mas powietrza, którym często towarzyszą opady deszczu (Soja 1997, 2008). Wówczas fale formowane w wyniku roztopów i opadów deszczu nakładają się na siebie, skutkując krótkotrwałymi wezbraniami z najwyższymi notowanymi przepływami i odpływami jednostkowymi (ryc. 2A). Tego typu genezę miały wezbrania w kwietniu 1964 r. $\left(113 \mathrm{dm}^{3} \cdot \mathrm{s}^{-1} \cdot \mathrm{km}^{-2}\right)$ oraz marcu i kwietniu $1969 \mathrm{r}$. $\left(q>300 \mathrm{dm}^{3} \cdot \mathrm{s}^{-1} \cdot \mathrm{km}^{-2}\right)$. W analizowanym ciągu przepływy wezbraniowe odnotowane podczas półrocza letniego są kilkukrotnie niższe i zwykle nie przekraczają $37 \mathrm{dm}^{3} \cdot \mathrm{s}^{-1} \cdot \mathrm{km}^{-2}$. Wyjątek stanowi wezbranie spowodowane opadami nawalnymi z dnia 18 maja $1996 \mathrm{r}$. z odpływem szacowanym na $474 \mathrm{dm}^{3} \cdot \mathrm{s}^{-1} \cdot \mathrm{km}^{-2}$ (Niedbała, Soja 1998). Przepływy maksymalne szacowane podczas tych wezbrań przekraczały wartości kulminacji kwietniowej. Na tej podstawie można stwierdzić, że podczas wezbrań, których kulminacje są wyższe niż $20 \mathrm{~m}^{3} \cdot \mathrm{s}^{-1}\left(296 \mathrm{dm} \mathrm{m}^{3} \cdot \mathrm{s}^{-1} \cdot \mathrm{km}^{-2}\right)$ istnieje duże prawdopodobieństwo wystąpienia znacznych strat materialnych. W 53-letnim ciągu przepływów dobowych obserwacji takie zdarzenia wystąpiły dwukrotnie. W pracy Partyki (1999) są wzmianki o ulewach powodujących wezbrania w dolinkach Prądnika, które nie zapisały się w obserwacjach hydrologicznych, jednak zdaniem autorów nie wpływają one istotnie na wzrost zagrożenia związanego z występowaniem dużych powodzi. W analizie przepływów wysokich warto zwrócić uwagę na przepływy dobowe $Q d>1,5 \mathrm{~m}^{3} \cdot \mathrm{s}^{-1}$, które na terenie OPN mogą spowodować wystąpienie rzeki z koryta (dokumentacja fotograficzna OPN). W ciągu 53 lat wystąpiły one 36 razy, co daje empiryczne prawdopodobieństwo wystąpienia ok. $0,5 \%$, czyli raz na dwa lata.

Podstawową cechą reżimu hydrologicznego rzek Polski jest występowanie okresów mokrych i posusznych (Fal, Bogdanowicz 2002). Podobne zależności występują w odpływie Prądnika. Wieloletnie okresy o podwyższonym/obniżonym w stosunku do średniej z wielolecia odpływie są w dużej mierze odbiciem zmian w zasilaniu zlewni opadami (Brzeźniak, Partyka 1998). Lata (np. 1961, 1964, 1983, 1984, 1985) bądź wielolecia (np. 1989-93, 1991-94, 2003-2006), które zaznaczyły się na większości rzek Polski niskimi odpływami (Fal, Bogdanowicz 2002; Bartnik, Jokiel 2012; Michalczyk 2017), zaznaczyły się również obniżonym odpływem Prądnika. Podobne zależności można również odnieść do lat wilgotnych (1977-1982, 1997-2002), które na większości rzek Polski powodowały zwiększony odpływ (Fal, Bogdanowicz 2002; Bartnik, Jokiel 2012; Michalczyk 2017) lub występowanie powodzi o zasięgu co najmniej regionalnym. W odpływie Prądnika są to np. lata: 1970, 1997, 1998, 2001, 2010 lub wielolecia, np. koniec lat 70. i początek 80. czy też końcówka lat 90. i początek XXI w. (ryc. 6A).

Wieloletnie zmiany w odpływie Prądnika, będące odbiciem zmian w zasilaniu zlewni opadami, są łagodzone przez dużą retencyjność zlewni związaną z górnojurajskim zbiornikiem wód podziemnych (Różkowski 1990; Leszkiewicz, Różkowski 2000; 
Bogacz, Łagiewka, 2004). Duży wpływ retencyjności zlewni na formowanie odpływu zdaje się potwierdzać zależność, która się pojawia pomiędzy rocznymi opadami a odpływem roku następnego (ryc. 6A, B). Statystycznie wyraża ją dosyć wysoki i istotny statystycznie współczynnik korelacji krzyżowej liczony z rocznym opóźnieniem $R_{c l}=0,6(p<0,05)$. Ten charakter zależności znany jest z innych rzek, a obserwowana bezwładność odpływu rzecznego ma związek z retencją wód podziemnych oraz sposobem i reżimem alimentacji rzek (Jokiel 2004). W Prądniku, podobnie jak w innych rzekach Polski (Jokiel 2004), przejawia się ona w tym, że w latach suchych (o niskim odpływie) wpływ opadu z roku poprzedzającego na odpływ jest większy niż opadu roku bieżącego. W latach mokrych różnica nie zaznacza się już tak wyraźnie (ryc. 6A, B).

W Prądniku relację pomiędzy opadem a odpływem można również rozpatrywać w kontekście funkcjonowania jurajskiego zbiornika wód podziemnych. Leszkiewicz i Różkowski (2000), analizując czas opóźnienia reakcji źródeł (drenujących ten sam zbiornik) na zasilanie, wykazali, że po opadach deszczu większą wydajność źródeł notuje się po ok. 200 dniach (pierwsze opóźnienie) i po ok. 375-750 dniach (drugie opóźnienie). Analizując korelogram przepływów niskich (ryc. 3C), można ocenić, na ile ten wpływ zaznacza się w odpływie. Miarą statystyczną tego wpływu powinny być podwyższone wartości współczynników autokorelacji $R a$, liczonych dla przesunięć ok. 6, 12-24 miesięcznych. Na korelogramie (ryc. 3G) we wskazanych przesunięciach nie zaobserwowano jednak podwyższonych wartości współczynników Ra. Można zatem stwierdzić, że zależności pomiędzy zasileniem i odpływem, które obserwuje się w układzie wieloletnim na podstawie analizy danych rocznych, nie są tak mocno zauważalne w krótszych okresach czasu. Prawdopodobnie jest to wpływ dużych możliwości retencyjnych zlewni, które warunkują dużą bezwładność odpływu. Zagadnienie to wymaga dalszych badań.

W Prądniku nie stwierdzono występowania istotnego statystycznie trendu w odpływie. Zmiany wskazujące na tendencję spadkową w Prądniku były bardziej zauważalne w krótszych seriach pomiarowych, 1961-1995 (Soja 1997), i były uwarunkowane niższymi odpływami początku lat 90., spowodowanymi mniejszymi opadami (Brzeźniak 2009). Niskie przepływy w tych latach były z pewnością częściowo pogłębione oddziaływaniem leja depresyjnego, który powstał głównie wskutek odwadniania kopalń rud cynku i ołowiu w rejonie Olkusza (Bogacz, Łagiewka 2004 za Wieczysty i in. 1990). Powodował on zanik wypływów w źródłowej części Prądnika na terenie Sułoszowej, jak też stopniowe obniżanie się poziomu wód jurajskich o kilka metrów (Bogacz, Łagiewka 2004 za Wieczysty i in. 1990). Warto zaznaczyć, że podobnie jak w Prądniku, brak trendu zmian odpływu w ostatnim półwieczu wykazano również w większych rzekach w całej Polsce (Fal, Bogdanowicz 2002).

W nielicznych opracowaniach hydrologii zlewni Prądnika zwracano uwagę na znaczny udział odpływu podziemnego w odpływie (Soja 1997, 2008). Analiza 
53-letniej serii dowodzi, że odpływ podziemny odgrywa kluczową rolę w odpływie całkowitym. Analiza struktury odpływu wskazuje na dużą rolę zbiornika wód podziemnych w obiegu wody w zlewni. Przykryte lessami, skrasowiałe wapienie jurajskie są zasilane przez wody infiltracyjne. Wskaźnik infiltracji efektywnej dla Prądnika jest najwyższy w tej części Wyżyny i wynosi 26\% (Różkowski, Żurek 2008). W rzekach tej części Wyżyny udział zasilania gruntowego mieści się zwykle w przedziale 60-80\% (Dynowska 1971). Dla Prądnika jest to wartość wyższa i dla badanego wielolecia wyniosła średnio 90\%. Dla poszczególnych miesięcy roku hydrologicznego jednostkowy odpływ podziemny przyjmuje wartości w przedziale $5,3-6,2 \mathrm{dm}^{3} \cdot \mathrm{s}^{-1} \cdot \mathrm{km}^{-2}$, przy średniej rocznej z wielolecia $5,8 \mathrm{dm}^{3} \cdot \mathrm{s}^{-1} \cdot \mathrm{km}^{-2}$ (tab. 1). Podobne wartości odpływu podziemnego otrzymano przy bilansowaniu górnojurajskiego zbiornika wodonośnego (Różkowski, Żurek 2008). W skali kraju są to wartości dosyć wysokie (por. Dynowska, Pociask-Karteczka 1998; Jokiel, Tomalski 2017) i wynikają ze sporych zasobów retencyjnych zlewni w silenie uszczelinionych i skrasowiałych skałach węglanowych (Bogacz, Łagiewka 2004). W porównaniu z sąsiadującymi zlewniami, których typ hydrogeologiczny jest podobny do Prądnika (Tomaszewski 2001), jednostkowe odpływy podziemne Prądnika są nieco wyższe. Różnice te maksymalnie wynoszą $1,5 \mathrm{dm}^{3} \cdot \mathrm{s}^{-1} \cdot \mathrm{km}^{-2}$. Minimalne wartości jednostkowych odpływów podziemnych w poszczególnych miesiącach mieszczą się w przedziale $3,0-3,6 \mathrm{dm}^{3} \cdot \mathrm{s}^{-1} \cdot \mathrm{km}^{-2}$ i odpowiadają najniższym odpływom miesięcznym $N N q m_{1961-2014}$ (ryc. 2). Biorąc to pod uwagę, można stwierdzić, że roczny przebieg najniższych przepływów dobrze oddaje charakter zasilania Prądnika przez wody jurajskiego zbiornika wód podziemnych w fazie długotrwałego drenażu zasobów wodnych tego zbiornika.

Analizując odpływ Prądnika w wieloleciu 1961-2014 i stosując klasyfikację I. Dynowskiej (1971), można potwierdzić, że rzeka ta ma „reżim wyrównany z wezbraniem wiosennym i letnim oraz gruntowo-deszczowo-śnieżnym zasilaniem”. Ustrój Prądnika można również określić jako śnieżny (niwalny) słabo wykształcony, w którym odpływ z miesięcy wiosennych nie przekracza $130 \%$ odpływu średniorocznego (Dynowska, Pociask-Karteczka 1998; Wrzesiński 2017).

\section{Podsumowanie}

Artykuł miał na celu całościową charakterystykę odpływu rzeki Prądnik w oparciu o analizę 53-letniej serii pomiarowej. Główne elementy podsumowania można wypunktować w postaci wniosków o różnej szczegółowości i wadze.

Prądnik charakteryzuje bardzo stabilny odpływ. Prawidłowość tę obserwuje się zarówno w roku hydrologicznym, jak również w wieloleciu. Analiza odpływu w 53-leciu potwierdza typ reżimu ustalony przez Dynowską (1971) dla rzek tej części Wyżyny na podstawie 10-letniej serii jako „reżim wyrównany z wezbraniem 
wiosennym i letnim oraz gruntowo-deszczowo-śnieżnym zasilaniem”, lub „śnieżny słabo wykształcony".

Odpływ Prądnika w wieloleciu ulegał zmianom będącym rezultatem zmiennego zasilania zlewni opadami. Lata lub wielolecia z podwyższonym/obniżonym odpływem Prądnika korespondują zwykle z tożsamymi okresami odnotowanymi na innych rzekach Polski. W 53-letniej serii nie stwierdzono istotnych statystycznie zmian odpływu. Podobne zależności charakteryzowały większe rzeki Polski w ostatnim półwieczu.

Zasoby wodne zlewni są duże. Średni roczny odpływ z wielolecia wyniósł $S S q_{1961-2014}-6,5 \mathrm{dm}^{3} \cdot \mathrm{s}^{-1} \cdot \mathrm{km}^{-2}$. Jest on nieco wyższy niż średnia dla Polski, ale porównywalny z innymi zlewniami krasowymi Wyżyny, mimo iż różnice w budowie geologicznej i krążeniu wód podziemnych zasilających te rzeki są nieco inne.

W strukturze odpływu dominuje odpływ podziemny, który stanowi średnio 90\%, a jego średnia wartość roczna dla wielolecia wynosi $5,8 \mathrm{dm}^{3} \cdot \mathrm{s}^{-1} \cdot \mathrm{km}^{-2}$. Jest to wartość nieco wyższa niż w zlewniach sąsiednich tej części Wyżyny.

\section{Podziękowanie}

Autorzy dziękują Dyrekcji i Pracownikom Ojcowskiego Parku Narodowego za udostępnienie niezbędnych materiałów, które pozwoliły zrealizować podjęty temat badawczy. Praca częściowo wykonana w ramach stażu odbytego w czerwcu 2015 r. w OPN.

\section{Literatura}

Alexandrowicz S.W., Wilk Z., 1962, Budowa geologicæna i \&ródta doliny Pradnika w Ojcowskim Parku Narodowym, Studia Naturae, 28, 187-210.

Bartnik A., Jokiel P., 2000, Średni odptyw podziemny w Polsce w latach 1971-1990 w swietle wyników uzyskanych metodami: Wundt'a i Kille'go, Gospodarka Wodna, 2, 56-59.

Bartnik A., Jokiel P., 2012, Geografia wezbrań i powodzi rzecznych, Wyd. UŁ., Łódź.

Bogacz A., Łagiewka R., 2004, Warunki wodne [w:] B. Radwanek-Bąk (red.), Objaśnienia do mapy geośrodowiskowej Polski 1:50 000, arkusz Skata, PIG, MŚ, Warszawa.

Brzeźniak E., 2009, Struktura czasowa opadów atmosferycznych w Ojcowie, Prądnik. Prace i Materiały Muzeum im. Prof. Wł. Szafera, 19, 53-66.

Brzeźniak E., Partyka J., 2008, Warunki klimatyczne Ojcowskiego Parku Narodowego [w:] A. Klasa, J. Partyka (red.), Monografia Ojcowskiego Parku Narodowego. Przyroda, OPN, Ojców, 121-136.

Chełmicki W., Baścik M., Korska A., Pociask-Karteczka J., Siwek J., 2001, Źródta Wyżyny Krakowsko-Wielunskiej i Miechowskiej. Zmiany w latach 1973-2000, IGiPZ UJ, Kraków.

Dynowska I., 1971, Typy reżimów ræecznych w Polsce, Zeszyty Naukowe UJ, Prace Geograficzne, 20,1-150. 
Dynowska I., 1979, Charakterystyka źódet Wyżyny Krakowesko-Wieluńskiej, Studia Ośrodka Dokumentacji Fizjograficznej, 7, 391-421.

Dynowska I., Pociask-Karteczka J., 1998, Obieg wody [w:] L. Starkel (red.), Geografia Polski. Środowisko Przyrodnicze, PWN, Warszawa, 343-373.

Fal B., Bogdanowicz E., 2002, Zasoby wód powierzchniowych Polski, Wiadomości IMGW, 25 (2), 5-38.

Jokiel P., 1994, Zasoby, odptyw i odnawialność wód podziemnych strefy aktywnej wymiany w Polsce, Acta Geographica Lodziensia, 66, 67, 1-236.

Jokiel P., 2004, Zasoby wodne środkowej Polski na progu XXI wieku, Wyd. UŁ, Łódź.

Jokiel P., Tomaszewski E., 2015, Analiza faz i form odptywu zlewni rzecznej na przykładzie Dzier:̈qznej [w:] P. Jokiel (red.), Metody statystycæne w analizach hydrologicwnych środkowej Polski, Wyd. UŁ, Łódź, 50-67.

Jokiel P., Tomalski P., 2017, Odphyw ræeczny w Polsce; formy odpływu ræecznego i ich zró:̇nicowanie przestrzenne [w:] P. Jokiel, W. Marszelewski, J. Pociask-Karteczka (red.), Hydrologia Polski, PWN, Warszawa, 160-167.

Kondracki J., 1937, Skutki ulewy w dniu 22 maja 1937 r. w dolinie Prądnika, Przegląd Geograficzny, 16, 161-165.

Kubiak-Wójcicka K., 2010, Zmienność przeptywów i sasobów wodnych rzeki Gwdy [w:] D. Wrzesiński (red.), Odpływ ræeczny i jego regionalne uwarunkowania, Bogucki Wydawnictwo Naukowe, Poznań, 99-107.

Leszkiewicz J., Różkowski J., 2000, Response of karst-fissure springs to infiltration recharge in the area of Ojców National Park (Cracow Upland, southern Poland), Kras i Speleologia, 10, 27-44.

Łajczak A., 1988, Opady i odptyw w polskich Tatrach w świetle pomiarów wieloletnich, Czasopismo Geograficzne 2, 137-170.

Mayaud C., Wagner T., Benischke R., Birk S., 2016, Understanding changes in the hydrological behaviour within a karst aquifer (Lurbach system, Austria), Carbonates and evaporites, 31(4), 357-365.

Michalczyk Z. 2017, Odpływ ræeczny w Polsce, odptyw średni, zmienność w czasie i zró:̇nicowanie przestrzenne [w:] P. Jokiel, W. Marszelewski, J. Pociask-Karteczka (red.), Hydrologia Polski, PWN, Warszawa, 153-160.

Niedbała J., Soja R. 1998, Odptyw z opadu nawalnego w dniu 18 maja 1996 roku w Sutoswowej [w]: L. Starkel (red.), Geomorfologiczny i sedymentologiczny zapis lokalnych ulew, Dokumentacja Geograficzna IGiPZ PAN, 11, 31-38.

Ozga-Zielińska M., Brzeziński J., 1994, Hydrologia stosowana, PWN, Warszawa.

Pawlak I., (red.) 1979, Mapa geologiczna Polski (bez utworów czwartorzędowych) 1:200 000, arkusz Tarnów, Wyd. Geologiczne, Warszawa.

Partyka J., 1999, Powodzie w dolinie Prądnika a ochrona Ojcowskiego Parku Narodowego [w:] Przyczyny i skutki wielkich powodzi (aspekty hydrologiczne, gospodarcze i spoteczne), Wyd. Muzeum Przyrodnicze PAN, Kraków, 129-134.

Perrin J.L., Tournoud M.G. 2009, Hydrological processes controlling flow generation in a small Mediterranean catchment under karstic influence, Hydrological Sciences Journal, 54(6), 1125-1140. 
Płonczyński J., (red.) 2000, Objaśnienia do szczegótowej mapy geologicznej Polski 1:50 000, arkusz Skata, MŚ, PIG, Warszawa.

Różkowski A., (red.), 1990, Szczelinowo-krasowe zbiorniki wód podziemnych Monokliny Ślasko-Krakowskiej i problemy ich ochrony, Wyd. SGGW, AR, Warszawa.

Różkowski J., Grabala D., Polonius A., 2015, Polska w projekcie World Karst Aquifer Mapping Project (WOKAM), Przegląd Geologiczny 63, 1042-1046.

Różkowski J., Pacholewski A., 1996, Bilanse wodne slewni reprezentatywnych w utworach weglanowych jury Wyżyny Krakowsko-Wieluńskiej, Przegląd Geologiczny, 44(8), 850-854.

Różkowski A., Żurek E., 2008, Zasoby wód podziemnych obszarów chronionych górnojurajskiego poziomu wodonośnego w regionie krakowskim [w:] J. Partyka, J. Pociask-Karteczka (red.), Wody na obszarach chronionych, IGiGP UJ, OPN, KH PTG, Kraków, 247-254.

Siwek J., 2004, Źródta w zlewniach Prqdnika, Dtubni i Szreniawy. Naturalne i antropogeniczne uwarunkowania jakości wód, IGiGP UJ, Kraków.

Siwek J., Baścik M. (red.), 2013, Przyrodnicze i antropogeniczne przemiany źódet Wyżyn Krakowsko-Wieluńskiej i Miechowskiej oraz ich rola w krajobrazie naturalnym i kulturowym, IGiGP UJ, Kraków.

Soja R., 1997, Operat hydrologiczny zlewni rzeki Pradnik w granicach Ojcowskiego Parku Narodowego, maszynopis, OPN, Ojców.

Soja R., 2008, Hydrologia Ojcowskiego Parku Narodowego [w:] A. Klasa, J. Partyka (red.), Monografia Ojcowskiego Parku Narodowego. Przyroda, OPN, Ojców, 97-120.

Stachy J., Biernat B., 1987, Średni niski odphyw jednostkowy (1951-1970) [w:] J. Stachy (red.), Atlas hydrologiczny Polski, IMGW, Wyd. Geologiczne, Warszawa, 56.

Tomalski P., Tomaszewski E., 2015, Metody, formuty $i$ wzory obliczeniowe zastosowane w pracy [w:] P. Jokiel (red.), Metody statystyczne w analizach hydrologicænych środkowej Polski, Wyd. UŁ, Łódź, 215-271.

Tomaszewski E., 2001, Sezonowe zmiany odptywu podziemnego w Polsce w latach 1971-1990, Acta Geographica Lodziensia, 79, 1-149.

Wieczysty A., Fiałkowski J., Kawalec T., 1990, Opinia o præyczynach obniżania siępoziomu wody podziemnej w pótnocno-zachodniej čęści woj. krakowskiego, maszynopis, Instytut Inżynierii Sanitarnej i Ochrony Środowiska Politechniki Krakowskiej, Kraków.

Wrzesiński D., 2017, Reżimy rzek Polski [w:] P. Jokiel, W. Marszelewski, J. Pociask-Karteczka (red.), Hydrologia Polski, PWN, Warszawa, 215-221.

Zeliaś A., 2000, Metody statystyczne, PWE, Warszawa.

Ziemońska Z., 1971, Charakterystyka hydrograficzna dwóch \&lewni krasowych, górskiej i wyżynnej na przyktadzie potoku Kościeliskiego i Prądnika, Zeszyty Naukowe UJ, Prace Geograficzne, 29, 95-102.

Tomasz Bryndal, Rafat Kroczak, Roman Soja, Marta Cieślik

Uniwersytet Pedagogic ny w Krakowie

Instytut Geografii

ul. Podchorqȧych 2, 30-082 Kraków

tbryndal@up.krakow.pl

soja.roman@up.krakow.pl 
